\title{
HYDRATION METHODS AND PHYSIOLOGICAL POTENTIAL OF SWEET CORN SEEDS
}

\author{
MÉTODOS DE HIDRATAÇÃO E POTENCIAL FISIOLÓGICO DE SEMENTES DE \\ MILHO DOCE
}

\author{
Jéssica de Lucena MARINHO ${ }^{1}$; Inês Cristina de Batista FONSECA ${ }^{1}$; Claudemir ZUCARELI $^{1}$ \\ 1. Universidade Estadual de Londrina/UEL, Departamento de Agronomia, Londrina, Paraná, Brasil. jlmarinho@live.com
}

\begin{abstract}
The evaluation of the physiological potential of sweet corn seeds is fundamental in the production process, because the germination and vigor reflect the potential for storage, commercialization and use of these seeds. The choice of vigor tests with an adequate and efficient analysis methodology is fundamental to obtaining reliable results. In this sense, the objective of this study was to assess the physiological potential of sweet corn seeds after hydration using different moistening methods to increase water content to $20 \%$. First, the lot of seeds was characterized as to its moisture content and initial physiological potential. Subsequently, two experiments were conducted, both under a completely randomized design. In the first experiment, different volumes of water on the filter paper sheets were assessed for seed hydration a method that uses a wet substrate. In the second, four hydration methods were evaluated: wet substrate (WS), humid atmosphere (HU), immersion in water (IW) and addition of the required amount of water (WR). A constant temperature of $25^{\circ} \mathrm{C}$ was used in both experiments and then the moisture content and physiological potential of seeds were determined. The humid atmosphere method reduces the physiological quality of sweet corn seeds because it favors the deterioration and hence is unsuitable for the hydration of seeds of this species. The wet substrate method, in an amount equivalent to 2.5 times the paper mass, increased the water content of sweet corn seeds to $20 \%$, achieving the desired degree of moisture without altering their physiological potential.
\end{abstract}

KEYWORDS: Germination. Moisture Content. Vigor. Zea mays convar. Saccharata.

\section{INTRODUCTION}

Sweet corn is a type of a special corn indicated for human consumption whose the seeds have specific characteristics (ALVARENGA; MARCOS FILHO; TIMÓTEO, 2013). They differ drastically from ordinary corn seeds regarding the structure and thickness of the pericarp and the chemical composition of the endosperm. These differences are due to the fact that sweet corn seeds have less amount of starch in their endosperm compared to ordinary corn seeds, due to the action of mutant alleles that prevent the conversion of monosaccharides (sugars) into polysaccharides (starch) (LUZ et al., 2014).

The wrinkled aspect and the lower thickness of the pericarp of sweet corn seeds make them more susceptible to damage during the germination or vigor test procedures. This makes it more difficult to assess the quality of the seeds, since such damage, mostly physiological, such as imbibition damage (ALVARENGA; MARCOS FILHO; TIMÓTEO, 2013), may underestimate the results obtained in seed tests that require previous moistening.
Water absorption by seeds is a physical process, as it occurs also in dead seeds, and its purpose is the activation of metabolic activities, which result in the breakdown of the molecules, releasing the energy and nutrients necessary for the growth and development of the embryonic axis (MARCOS FILHO, 2015). However, accelerated imbibition caused by excess water in the substrate or by damage to the seed coat can lead to the disorganization of membranes and tissue rupture, which favors anaerobic respiration, leading to irreversible damage (ROSSETTO et al., 1997; ZUCARELI et al., 2008).

The water potential of seeds has a direct impact on seed imbibition rate, and its definition considers the initial moisture content. The water potential of dried seeds is generally lower than that of the substrate used in the germination or vigor test and, therefore, there is movement of water molecules from the substrate into the seed (ZUCARELI et al., 2008). Therefore, due to the particularities of this species, the selection of a suitable substrate that does not contain excessive moisture, is very important, since studies on seeds from other species, e.g. beans, found that the 
substrate interferes with the availability of water and, consequently, with the speed and percentage of germination of seeds (SHIOGA; SILVA, 1998; GORDIN; SCALON; MASETTO, 2015).

Vigor tests that require previous seed moistening and standardization of seed moisture content, such as tetrazolium and controlled deterioration, must be carefully investigated, so that the wetting process does not affect seed quality and do not underestimate the result obtained. Thus, the definition of an appropriate methodology for hydration, especially of seeds more susceptible to damage, is essential (ZUCARELI et al., 2008).

Based on the aforementioned, Hampton; Tekrony (1995) recommended three alternative methods to prevent seed damage during standardization of moisture content: humid atmosphere, addition of the required amount of water or wet substrate. The selection of the most appropriate method depends to a large extent on the intrinsic characteristics of the seed such as chemical composition (reserve material) (BEWLEY et al., 2013), permeability of the integument, area of contact of the seed (anatomy) (BECKERT; SILVA, 2002) and the initial physiological quality (ZUCARELI et al., 2008).

A moisture content around $20 \%$ has been used in different seed species to perform vigor tests that involve hydration, as in the controlled deterioration test (SILVA; VIEIRA, 2010; TORRES et al., 2012; TORRES et al., 2013).

In their study on the physiological potential of ordinary corn seeds after being submitted to hydration through the methods of humid atmosphere, wet substrate, immersion in water and addition of the required amount of water under two temperatures, 20 and $30^{\circ} \mathrm{C}$, Zucareli et al. (2011) found that the humid atmosphere method reduced the physiological quality of corn seeds and the method of direct immersion in water at $30^{\circ} \mathrm{C}$ did not impact the physiological quality of the seeds, being the most suitable for this purpose.

Therefore, the present study aimed to assess the physiological potential of sweet corn seeds after hydration under different hydration methods to reach a $20 \%$ water content.

\section{MATERIAL AND METHODS}

The research was done at the Seed Analysis Laboratory of the Agronomy Department of State University of Londrina, in Londrina, Parana state.

A lot of hybrid seeds of super sweet corn, a carrier of the shrunken (sh2) gene was used in the study. The lot was initially homogenized and then sampled for preliminary analyzes, which indicated the initial seed quality:

Water content: determined with four replicates of 15 whole seeds, submitted to oven at $105{ }^{\circ} \mathrm{C} \pm 2{ }^{\circ} \mathrm{C}$, for 24 hours, in accordance with the Rules for Seed Testing (BRASIL, 2009).

Germination: conducted with four replicates of 100 seeds, on moistened germitest paper in an amount equivalent to 2.5 times the substrate (paper) mass at a temperature of $25{ }^{\circ} \mathrm{C}$, with evaluation seven days after the installation of the test (BRASIL, 2009).

First count: performed concomitantly with the germination test and using the same methodology, with evaluation on fourth day after sowing.

Cold test: conducted through the method of rolled paper towel without soil, with four replicates of 100 seeds sown on moist germitest paper in an amount equivalent to 2.5 times its mass, and kept at $10{ }^{\circ} \mathrm{C}$ for seven days, and at $25^{\circ} \mathrm{C}$ for four days, for the count of normal seedlings.

Accelerated aging: use of four replicates of 120 seeds aged at a temperature of $42{ }^{\circ} \mathrm{C}$ for 72 hours. Four replicates of 15 seeds were used to determine the water content, and four replicates of 100 seeds were submitted to the germination test, and count was performed four days after sowing (AOSA, 2009).

Electrical conductivity: four replicates of 50 seeds with the previously determined masses were imbibed in $25 \mathrm{~mL}$ of distilled water for a period of 24 hours at $25{ }^{\circ} \mathrm{C}$ (PARERA et al., 1995).

Length of normal seedlings: measurement began after the sowing of four replicates of 10 seeds per treatment, in the upper third of the germitest paper, kept in germinator for four days in darkness, at $25{ }^{\circ} \mathrm{C}$. Subsequently, the length of normal seedlings, separated in shoot and roots, was measured with the aid of a ruler graduated in centimeters.

Dry mass of normal seedlings: assessed with the use of the normal seedlings obtained in the test of length, and these seedlings were separated into shoot and roots. The parts were oven dried with forced air circulation, at a temperature of $80{ }^{\circ} \mathrm{C} \pm 5$ ${ }^{\circ} \mathrm{C}$ until reaching constant mass. Subsequently, the mass of seedlings was assessed for each replicate in precision scale.

Emergence of seedlings in sand substrate: carried out using four replicates of 50 seeds, which were sown in sandboxes at a 5-cm depth. Fourteen (14) days after sowing, the number of emerged seedlings was counted, and the result was expressed in percentage. 
Rate of seedling emergence: conducted concomitantly with the emergence of seedlings in sand substrate, and counts were made daily from the emergence of the first seedling until the 14th day. Based on the number of seedlings emerged for each reading, the rates of seedling emergence (IVE) were calculated (MAGUIRE, 1962).

The lot of sweet corn seeds showed high values of germination and vigor, being suitable for evaluation of hydration methods (Table 1), since lots of seeds with low physiological potential, especially those with percentages of germination lower than the minimum values established for commercialization, are not recommended for studies of methods of seed hydration (ZUCARELI et al., 2008).

Table 1. Characterization of moisture and initial physiological potential (germination and vigor) of the lot of sweet corn seeds used in the experiment

\begin{tabular}{cccccccccccccc}
\hline $\mathrm{U}(\%)$ & $\begin{array}{c}\mathrm{G} \\
(\%)\end{array}$ & $\begin{array}{c}\mathrm{FC} \\
(\%)\end{array}$ & $\begin{array}{c}\mathrm{AS} \\
(\%)\end{array}$ & $\begin{array}{c}\mathrm{DS} \\
(\%)\end{array}$ & $\begin{array}{c}\mathrm{CT} \\
(\%)\end{array}$ & $\begin{array}{c}\mathrm{AA} \\
(\%)\end{array}$ & $\begin{array}{c}\mathrm{EC} \\
(\mu \mathrm{S} / \mathrm{cm} / \mathrm{g})\end{array}$ & $\begin{array}{c}\mathrm{SL} \\
(\mathrm{cm} / \mathrm{pl})\end{array}$ & $\begin{array}{c}\mathrm{RL} \\
(\mathrm{cm} / \mathrm{pl})\end{array}$ & $\begin{array}{c}\mathrm{DMS} \\
(\mathrm{mg} / \mathrm{pl})\end{array}$ & $\begin{array}{c}\mathrm{DSR} \\
(\mathrm{mg} / \mathrm{pl})\end{array}$ & $\begin{array}{c}\mathrm{ES} \\
(\%)\end{array}$ & $\mathrm{RSE}$ \\
\hline 7,99 & 91 & 79 & 6 & 3 & 56 & 78 & 156 & 3,30 & 8,01 & 9,20 & 6,99 & 91 & 4,32 \\
\hline
\end{tabular}

Legend: Plant (pl); moistening level (U); germination (G); first germination count (FC); abnormal seedlings (AS); dead seeds (DS); cold test (CT); accelerated aging (AA); electrical conductivity (EC); shoot length (SL); root length (RL); dry mass of shoot (DMS); dry mass of root (DMR); emergence of seedlings in sand substrate (ES); rate of seedling emergence (RSE).

Source: data provided by the author

Subsequently, two experiments were conducted to determine the best hydration method for sweet corn seeds. The experimental design used in both experiments was completely randomized. In the first experiment, five water contents were evaluated in the wet substrate, with four replications, to raise the moisture content to $20 \%$ : equivalent to $1.5 ; 2.0 ; 2.5 ; 3.0$ and 3.5 times the paper mass. During moistening, seed rolls were kept in a germination chamber at $25^{\circ} \mathrm{C}$.

In the second experiment, four hydration methods were evaluated: wet substrate (WS), humid atmosphere (HU), immersion in water (IW) and adding required amount of water (WR) to raise the moisture content of the seeds to $20 \%$, under a constant temperature of $25^{\circ} \mathrm{C}$, with 6 replicates.

The determination of the mass to be reached by the seeds to obtain a moisture content of $20 \%$ in both experiments was based on the initial mass and moisture of the seeds and was constantly monitored by weighing in analytical scale (HAMPTON; TEKRONY, 1995).

In the wet substrate method, three sheets of germitest paper were used, which were moistened with water at an amount equivalent to 2.5 times the paper mass, and then paper rolls were prepared and kept in a sort of BOD (biochemical oxygen demand) determination test chamber at $25{ }^{\circ} \mathrm{C}$ until the seeds reached the predetermined mass.

In the humid atmosphere method, each replicate was distributed over the metal screen of plastic boxes with a lid $(11 \mathrm{~cm} \times 11 \mathrm{~cm} \times 3.5 \mathrm{~cm})$, containing $40 \mathrm{~mL}$ of distilled water. The boxes were packed in plastic bags and kept in BOD chambers at a temperature of $25{ }^{\circ} \mathrm{C}$ until the seeds reached the mass previously determined for the moisture content of $20 \%$.

In the water immersion method, the seeds were placed in plastic containers and immersed in $100 \mathrm{~mL}$ of distilled water, and the containers were kept in BOD at $25{ }^{\circ} \mathrm{C}$. The water used for seed immersion was kept at the temperature used for the assay $\left(25^{\circ} \mathrm{C}\right)$. Before weighing, the seeds were dried superficially with paper towels for the monitoring of the mass obtained.

For the method of addition of the required amount of water, the volume of water required to raise the moisture content to $20 \%$ was previously calculated, considering the mass and the initial water content of each replicate. The seeds were stored in plastic bottles with a lid $(250 \mathrm{~mL}$ capacity), in which the volumes of distilled water were also calculated, and the bottles were kept in chambers regulated at a temperature of $25^{\circ} \mathrm{C}$ for 12 hours.

When the previously calculated mass was reached, the moisture content of ten seeds of each sample of the two experiments was determined, and the remainder was packed in sealed plastic bottles, which were kept in chambers at a temperature of 10 ${ }^{\circ} \mathrm{C}$ for five days, for standardization of the moisture content (ZUCARELI et al., 2008).

Subsequently, the moisture and the physiological properties of the seeds of the two experiments were determined through the following tests: first count of germination, germination test (normal, abnormal and dead seedlings), electrical conductivity, length of seedlings (separated in shoot and roots) and dry mass of seedlings (separated in 
shoot and roots), according to the previously described methodologies.

The data obtained was submitted to the analysis of normality and homogeneity of variances by the Bartlett and Shapiro-Wilk tests, and for the germination and first count tests after the hydration methods, the data were transformed to square root $\sqrt{x}$. Subsequently, they were submitted to analysis of variance and the means were compared by Tukey test, at $5 \%$ of significance.

\section{RESULTS AND DISCUSSION}

Experiment 1: water content in the wet substrate

A significant effect of the different water contents on the substrate was observed only for the first count of germination, germination (normal seedlings) and electrical conductivity (Table 2).

Table 2. Moisture level and physiological characteristics of sweet corn seeds imbibed with different volumes of water in paper substrate, through the wet substrate method.

\begin{tabular}{ccccccccccc}
\hline TREAT. & $\begin{array}{c}\mathrm{U} \\
(\%)\end{array}$ & $\begin{array}{c}\mathrm{G} \\
(\%)\end{array}$ & $\begin{array}{c}\mathrm{FC} \\
(\%)\end{array}$ & $\begin{array}{c}\mathrm{AS} \\
(\%)\end{array}$ & $\begin{array}{c}\mathrm{DS} \\
(\%)\end{array}$ & $\begin{array}{c}\mathrm{EC} \\
(\mu \mathrm{S} / \mathrm{cm} / \mathrm{g})\end{array}$ & $\begin{array}{c}\text { SL } \\
(\mathrm{cm} / \text { plant })\end{array}$ & $\begin{array}{c}\text { RL } \\
(\mathrm{cm} / \text { plant })\end{array}$ & $\begin{array}{c}\text { DMS } \\
(\mathrm{mg} / \text { plant })\end{array}$ & $\begin{array}{c}\text { DSR } \\
(\mathrm{mg} / \text { plant })\end{array}$ \\
\hline 1.5 & 19.68 & $88 \mathrm{ab}$ & $70 \mathrm{ab}$ & 5 & 8 & $113.71 \mathrm{a}$ & 4.10 & 7.38 & 8.50 & 5.50 \\
2.0 & 20.33 & $93 \mathrm{a}$ & $75 \mathrm{a}$ & 2 & 5 & $110.42 \mathrm{ab}$ & 3.53 & 7.25 & 6.82 & 4.75 \\
2.5 & 20.46 & $92 \mathrm{ab}$ & $73 \mathrm{a}$ & 2 & 7 & $104.29 \mathrm{~b}$ & 3.13 & 7.38 & 7.40 & 4.52 \\
3.0 & 21.31 & $89 \mathrm{ab}$ & $67 \mathrm{ab}$ & 5 & 6 & $104.96 \mathrm{~b}$ & 3.63 & 7.85 & 7.95 & 5.07 \\
3.5 & 20.54 & $87 \mathrm{~b}$ & $62 \mathrm{~b}$ & 5 & 8 & $116.71 \mathrm{a}$ & 3.10 & 7.40 & 6.25 & 4.97 \\
\hline P-Value & - & 0.04 & 0.01 & 0.53 & 0.17 & 0.00 & 0.08 & 0.94 & 0.51 & 0.92 \\
CV (\%) & 2.62 & 3.01 & 6.46 & 42,16 & 27.11 & 3.56 & 14.71 & 13.91 & 26.36 & 31.13 \\
\hline
\end{tabular}

Means followed by the same letter in the column do not differ by Tukey test at 5\% significance. Legend: treatments (TREAT.); coefficient of variation (CV); moistening level (U); Germination of normal seedlings (G); first germination count (FC); abnormal seedlings (AS); dead seeds (DS); electrical conductivity (EC); shoot length (SL); root length (RL); dry mass of shoot (DMS); dry mass of root (DMR).

Source: data provided by the author.

The wet substrate method with different water volumes in the paper was found to effectively adjust the seed moisture to a level of $20 \%$, (Table 2 ), considering that the difference in moisture content after hydration $(1.63 \%)$ was lower than the maximum difference allowed, of 2 to $3 \%$, ensuring a safe interpretation of the results (TOMES; TEKRONY; EGLI, 1988).

Although all the treatments showed a germination rate higher than $70 \%$, which is the minimum standard established for corn crop by Normative Ruling no 45 (BRASIL, 2013), the treatment consisting of a water volume equivalent to 2.0 times the paper mass showed a percentage of germination higher than the other treatments and higher than the percentage of initial germination (Table 2). The germination rate obtained with addition of a water volume equivalent to 2.5 times the paper mass, although not different from the germination rates after addition of water contents of 1.5 and 3.0, also showed a germination value above the initially obtained level. Thus, these two water contents in the substrate were suitable for the activation of membrane repair mechanisms and enzymatic activation without causing physiological damage (ZUCARELI et al., 2008), which accelerated the degradation of reserves and favored the formation of normal seedlings. The higher germination speed, represented by the values of the first count, confirms the greater effectiveness of the treatments with water volumes equivalent to 2.0 and 2.5 times the paper mass compared to the others.

On the other hand, the treatment with water volume corresponding to 3.5 times the paper mass showed a germination rate lower than the rates of the other treatments, and of the initial germination rate. The excess water in the substrate associated with the reduced water potential of the seeds may have caused accelerated imbibition, which causes tissue ruptures and membrane disorganization (ROSSETTO et al., 1997; ZUCARELI et al., 2008) and reduces the germination rate. Moreover, excess water on paper may have caused deficiency in oxygen supply, which is essential for germination. During imbibition, embryonic respiratory activity is intensified to supply energy to the metabolic processes responsible for the development of the embryonic axis, and oxygen is essential for these reactions. An excessive amount of water limits oxygen uptake, reducing respiration and retarding germination (TANAKA; MARIANO; LEÃO, 1991), which can be confirmed by the lower germination rate demonstrated in the first count of 
the treatment of addition of a water volume equivalent to 3.5 times the paper mass (Table 2).

As for the lower germination rates caused by high water contents in the substrate, as observed in this study, Silva; Carvalho (2008), in their study of faveira (Clitoria fairchildiana) seeds of different sizes, under four moistening levels of sand substrate $(25 \%, 50 \%, 75 \%$ and $100 \%$ of retention capacity) found that excess water imbibition reduced germination rates. This can be related to the increase of anaerobic respiration, which causes the death of tissues due to the greater production of toxic substances.

In their study of the effects of two substrates (germitest paper and blotter paper) and six water volumes (equivalent to $1.5 ; 2.0 ; 2.5 ; 3.0 ; 3.5 ; 4.0$ times the paper mass) on the germination of soybean seeds, with germination conducted on germitest paper, Jacinto; Benett; Benett (2014) found that the use of higher water volumes to moisten the substrate caused a linear reduction in the percentage of normal seedlings. For a water content equivalent to 3.5 times the paper mass, the authors obtained the lowest percentages of germination, corroborating the results of this study. However, the opposite was observed in the germination test conducted on substrate between blotter paper, which demonstrates the impact of the substrate on the availability of water for the seeds, as well as the need for studies on other substrates or hydration methods that are more suitable and cause less damage to corn seeds.

The electrical conductivity values observed in all treatments after moistening (Table 2) were lower than the initial electrical conductivity of the lot (Table 1), possibly due to the influence of the water content of the seeds on the test results. The lower the water content, the greater the disorganization of the membranes and, consequently, the greater the release of solutes, which increases the electrical conductivity value. Moreover, after imbibition, the membranes are reorganized, which minimizes the release of exudates (VIEIRA; KRZYZANOWSKI, 1999). Also, according to Zucareli et al. (2008), these lower values after hydration may also be associated with the loss of leachates during the moistening period that are transferred from the seed to the substrate, which subsequently reduced the amount of these electrolytes released to the imbibition solution.

The water volumes equivalent to 2.5 and 3.0 times the paper mass were more effective than the other treatments, because they had lower values of electrical conductivity, indicating that the membranes are more organized and have higher quality and, consequently, greater vigor. The higher electrical conductivity values detected in the treatment containing the highest amount of water in the substrate (3.5 times the paper mass) may be related to damage or ruptures in the membranes due to accelerated imbibition caused by the higher water content in the paper, which demonstrates the lower vigor of seeds submitted to hydration through this method (CARVALHO; NAKAGAWA, 2012; MARCOS FILHO, 2015).

The treatment with the lowest water content in the paper (equivalent to 1.5 times the substrate mass), extended the time required for the seeds to reach the expected water content, and during this period the seeds were exposed to unfavorable conditions that may have accelerated the aging process, producing a negative impact on their physiological quality (VILLELA; MARCOS FILHO; NOVEMBRE, 2003).

In general, in the wet substrate method (on germitest paper), the proportions of water content equivalent to 2.0 and 2.5 times the paper mass were found to be suitable for the hydration of sweet corn seeds, because they allow water uptake and increase the moisture level without damage that might impair the physiological potential of the seeds, corroborating the results obtained by Zucareli et al. (2008) for ordinary corn. However, since the amount of water equivalent to 2.5 times the paper mass has been widely used as reference for several species, and has shown slightly higher results, this amount is more suitable for the hydration of sweet corn seeds. However, other hydration methods should be evaluated to demonstrate the efficiency of the method that uses a wet substrate moistened with water equivalent to 2.5 times the paper mass.

Experiment 2: Methods for moistening sweet corn seeds

According to analysis of variance of the physiological characteristics of the seeds (Table 3), there was a significant effect of the treatments for the variables investigated, except for root length.

The methods assessed effectively increased the moisture content of the seeds to $20 \%$, and the maximum variation observed was 0.91 percentage point, which ensures uniformity and minimizes the impact of moisture in the comparisons of the effects of the different methods. 
Table 3. Moisture level and physiological characteristics of imbibition of sweet corn seeds using different hydration methods.

\begin{tabular}{ccccccccccc}
\hline TREAT. & $\begin{array}{c}\mathrm{U} \\
(\%)\end{array}$ & $\begin{array}{c}\mathrm{G} \\
(\%)\end{array}$ & $\begin{array}{c}\mathrm{FC} \\
(\%)\end{array}$ & $\begin{array}{c}\text { AS } \\
(\%)\end{array}$ & $\begin{array}{c}\mathrm{DS} \\
(\%)\end{array}$ & $\begin{array}{c}\text { EC } \\
(\mu \mathrm{s} / \mathrm{cm} / \mathrm{g})\end{array}$ & $\begin{array}{c}\text { SL } \\
(\mathrm{cm} / \text { plant })\end{array}$ & $\begin{array}{c}\text { RL } \\
(\mathrm{cm} / \text { plant })\end{array}$ & $\begin{array}{c}\text { DMS } \\
(\mathrm{mg} / \mathrm{plant})\end{array}$ & $\begin{array}{c}\text { DMR } \\
(\mathrm{mg} / \mathrm{plant})\end{array}$ \\
\hline HU & 21.1 & $76 \mathrm{~b}$ & $48 \mathrm{c}$ & $14 \mathrm{a}$ & $10 \mathrm{a}$ & $166.61 \mathrm{a}$ & $4.08 \mathrm{a}$ & 8.24 & $11.12 \mathrm{a}$ & $8.18 \mathrm{~b}$ \\
WS & 20.8 & $88 \mathrm{a}$ & $75 \mathrm{a}$ & $8 \mathrm{~b}$ & $4 \mathrm{bc}$ & $116.02 \mathrm{~b}$ & $4.02 \mathrm{a}$ & 9.17 & $11.34 \mathrm{a}$ & $8.81 \mathrm{ab}$ \\
IW & 20.8 & $92 \mathrm{a}$ & $61 \mathrm{~b}$ & $6 \mathrm{~b}$ & $3 \mathrm{c}$ & $142.32 \mathrm{ab}$ & $3.05 \mathrm{~b}$ & 8.43 & $877 \mathrm{~b}$ & $10.98 \mathrm{a}$ \\
WR & 20.2 & $74 \mathrm{~b}$ & $53 \mathrm{bc}$ & $18 \mathrm{a}$ & $8 \mathrm{ab}$ & $172.35 \mathrm{a}$ & $3.44 \mathrm{ab}$ & 8.66 & $8.93 \mathrm{~b}$ & $10.06 \mathrm{ab}$ \\
\hline P-Value & - & 0.00 & 0.00 & 0.00 & 0.00 & 0.01 & 0.00 & 0.43 & 0.00 & 0.01 \\
CV $(\%)$ & 2.82 & 2.81 & 5.13 & 16.37 & 43.05 & 19.86 & 11.47 & 11.63 & 11.69 & 14.81 \\
\hline
\end{tabular}

Means followed by the same letter in the columns do not differ by the Tukey test at 5\% significance. Legend: Treatments (TREAT.); humid atmosphere (HU); wet substrate (WS); direct immersion in water (IW); addition of required amount of water (WR); coefficient of variation (CV); degree of humidity (U); germination of normal seedlings $(\mathrm{G})$; first germination count (FC); abnormal seedlings (AS); dead seeds (DS); electrical conductivity (EC); shoot length (SL); root length (RL); dry mass of shoot (DMS); dry mass of root (DMR). Source: information provided by the author.

The methods tested resulted in germination values higher than $70 \%$, which is the minimum standard established by Normative Ruling no. 45 (BRASIL, 2013). However, the wet substrate method and direct water immersion methods were the most effective because their values for germination, abnormal seedlings and dead seeds were similar to those observed in the seeds before imbibition (Table 1), which indicates the best quality of the seeds submitted to hydration through these processes.

On the other hand, the methods addition of required amount of water and, again, humid atmosphere showed the lowest percentages of germination due to the greater number of abnormal seedlings and dead seeds, with the number of abnormal seedlings higher than the number of dead seeds. These two methods reduced the physiological potential of the seeds, either by causing imbibition damage to the membranes, in the method of addition of the required amount of water (HAMPTON; TEKRONY, 1995), or by accelerating the aging process due to the long imbibition period, in the humid atmosphere method (VILLELA; MARCOS FILHO; NOVEMBRE, 2003).

According to Villela; Novembre; Marcos Filho (2007), degradation of proteins and insoluble carbohydrates, in seeds with reduced physiological potential, is detrimental to vigor and germination, since these compounds are responsible for water uptake. Thus, increasing the moisture content of seeds through inadequate methods that accelerate deterioration processes, such as humid atmosphere and addition of the required amount of water, reduce not only vigor but also the normal ability of seeds to germinate.

The wet substrate method showed the highest value of first count of germination, which was also the closest to the value of first count of germination of the lot of seeds not initially hydrated (Table 1). Thus, this method is suitable for seed moistening, as it does not have a negative impact on germination speed. The other methods showed lower values for this variable, with emphasis on the humid atmosphere method, which may be related to the long period required to raise the water content, in which the seeds are exposed to a high degree of humidity that accelerates the aging processes associated with the water content (VILLELA; MARCOS FILHO; NOVEMBRE, 2003).

The wet substrate method showed lower values of electrical conductivity, followed by the water immersion method, which did not differ statistically from the others. On the other hand, the methods of addition of the required amount of water and humid atmosphere provided higher conductivity values. Regarding electrical conductivity, the lower the value, the higher the quality of the seed; and the higher the value, the greater the degree of deterioration of the lot because of the greater amount of exudates released by the membrane.

According to Silva; Rosseto (2012), the higher conductivity value obtained for seeds submitted to the humid atmosphere method may be related to slow imbibition of seeds in this procedure, due to the lower availability of water vapor, which prolongs the time of exposure of the seeds to a humid atmosphere, favoring deterioration. On the other hand, adding the required amount of water may result in imbibition damage to the membranes, which, according to Hampton; Tekrony (1995), is one of the limitations of this method. This characterizes the beginning of the degenerative changes in the seeds and culminates in their lower vigor (DELOUCHE, 2002), as demonstrated in the electrical conductivity test. 
Regarding the length of the shoot, the methods wet substrate and humid atmosphere showed the highest values, followed by the method of addition of the required amount of water, which did not differ statistically from the previous ones nor from the water immersion method, the latter being the one with the lowest value. Regarding root length, no significant difference was observed between the methods investigated. However, the wet substrate method presented the highest value for this characteristic, standing out positively from the others.

A higher dry shoot mass was obtained with the methods wet substrate and humid atmosphere. Regarding the dry mass of roots, a higher value was obtained with the water immersion method. However, the methods wet substrate and addition of the required amount of water did not differ statistically from the water immersion method, nor from the humid atmosphere method, which showed the lowest value.

In a study of four hydration methods (wet substrate, humid atmosphere, immersion in water and addition of the amount of water required) to raise the moisture content of corn seeds, Zucareli et al. (2011) found that the humid atmosphere method reduced the physiological potential of the seeds, corroborating the results obtained for the different characteristics assessed in the present study. On the other hand, the authors found that a temperature of $30{ }^{\circ} \mathrm{C}$ and the method of direct immersion in water did not alter the physiological quality of ordinary corn seeds, being suitable for the hydration of these seeds, diverging from the results of this study.
Silva; Rosseto (2012), in their assessment of the physiological quality of sunflower seeds after hydration through the humid atmosphere and wet substrate methods at temperatures of 10 and $20^{\circ} \mathrm{C}$, found that the method of wet substrate at $10{ }^{\circ} \mathrm{C}$ effectively raised the moisture content, similarly to the results obtained here, except for the temperature. However, for sunflower, seedling vigor was reduced.

Of all the procedures analyzed, the wet substrate method showed results higher than or statistically equivalent to the results of the other methods for all the variables analyzed. In addition, this method has not adversely affected the physiological potential of the seeds and can be considered fast and easy to perform, which is essential for large-scale use. On the other hand, the method of humid atmosphere is time consuming and reduced the physiological potential of the seeds. Thus, it is unsuitable for raising the moisture content of sweet corn seeds.

\section{CONCLUSIONS}

The humid atmosphere method reduces the physiological potential of sweet corn seeds and is unsuitable for the hydration of seeds of this species.

The wet substrate method, in an amount equivalent to 2.5 times the paper mass was suitable for raising the moisture content of sweet corn seeds to $20 \%$, by allowing the desired degree of moisture to be obtained without altering the physiological potential of the seeds.

RESUMO: A avaliação do potencial fisiológico de sementes de milho doce é fundamental no processo de produção, pois a germinação e o vigor refletem o potencial de armazenamento, comercialização e utilização dessas sementes. A escolha de testes de vigor com uma metodologia de análise adequada e eficiente é fundamental para a obtenção de resultados confiáveis. Nesse sentido, o objetivo deste estudo foi avaliar o potencial fisiológico de sementes de milho doce após hidratação sob diferentes métodos de umedecimento, visando elevar o teor de água para $20 \%$. O lote de sementes foi caracterizado quanto a umidade e o potencial fisiológico inicial. Posteriormente, foram conduzidos dois experimentos, ambos sob delineamento inteiramente casualizado. No primeiro, foram avaliadas diferentes quantidades de água no papel para hidratação das sementes pelo método do substrato úmido. No segundo, foram avaliados quatro métodos de umedecimento: substrato úmido (WS), atmosfera úmida (HU), imersão em água (IW) e adição da quantidade de água requerida (WR). Em ambos experimentos foi utilizada temperatura constante de $25^{\circ} \mathrm{C}$ e, posteriormente, foram determinados a umidade e o potencial fisiológico das sementes. O método da atmosfera úmida reduz a qualidade fisiológica das sementes de milho doce pois favorece a deterioração, sendo inadequado para a hidratação de sementes desta espécie. O método do substrato úmido, na proporção de 2,5 vezes a massa do papel em água, mostrou-se adequado para a elevação do teor de água de sementes de milho doce para 20\%, por permitir a obtenção do grau de umidade desejado sem alterar o potencial fisiológico.

PALAVRAS-CHAVE: Germinação. Teor de Água. Vigor. Zea mays convar. Saccharata. 


\section{REFERENCES}

ALVARENGA, R.O.; MARCOS FILHO, J.; TIMÓTEO, T.S. Assessment of the physiological potential of super sweet corn seeds. Journal of Seed Science, v. 35, n. 3, p. 340-346, 2013.

http://dx.doi.org/10.1590/S2317-15372013000300010

AOSA - Association of official seed analysts. Seed vigor testing handbook. Lincoln, 2009. 105p.

BECKERT, O.P.; SILVA, W.R. O uso da hidratação para estimar o desempenho de sementes de soja.

Bragantia, v. 61, n. 01, p. 61-69, 2002. http://dx.doi.org/10.1590/S0006-87052002000100010

BEWLEY, J.D.; BRADFORD, K.; HILHORST, H.W.M.; NONOGAKI, H. Seeds: Physiology of

Development, Germination and Dormancy, 3rd edition. Nova York: Springer, 2013. 392 p.

BRASIL. Ministério da Agricultura, Pecuária e Abastecimento. Regras para análise de sementes. Brasília: Mapa/ACS, 2009. 399 p.

BRASIL. Ministério da Agricultura, Pecuária e Abastecimento. Instrução Normativa $N^{\circ} 45$ de 2013. Brasília, DF: MAPA/DAS/CSM, 2013, 38 p.

CARVALHO, N.M.; NAKAGAWA, J. Sementes: ciência, tecnologia e produção. Jaboticabal: FUNEP, 2012. $590 \mathrm{p}$.

DELOUCHE, J.C. Germinação, deterioração e vigor da semente. Seed News, v. 6, n. 6, p. 24-31, 2002.

GORDIN, C.R.B.; SCALON, S.P.Q.; MASETTO, T.E. Disponibilidade hídrica do substrato e teor de água da semente na germinação de niger. Pesquisa Agropecuária Tropical, v. 45, n. 3, p. 312-318, 2015.

http://dx.doi.org/10.1590/1983-40632015v4535337

HAMPTON, J.G.; TEKRONY, D.M. Controlled deterioration test. In: HAMPTON, J.G., TEKRONY, D.M. Handbook of vigour test methods. Zurich: International Seed Testing Association, p.70-78. 1995.

JACINTO, J.T.D.; BENETT, K.S.S.; BENETT, C.G.S. Influência do substrato e do teor de água sobre a germinação de sementes de soja. Revista de Agricultura Neotropical, v. 1, n. 1, p. 97-102, 2014. https://doi.org/10.32404/rean.v1i1.219

LUZ, J.M.Q.; CAMILO, J.S.; BARBIERI, V.H.B.; RANGEL, R.M.; OLIVEIRA, R.C. Produtividade de genótipos de milho doce e milho verde em função de intervalos de colheita. Horticultura Brasileira, v. 32, n. 2, p. 163-167, 2014. http://dx.doi.org/10.1590/S0102-05362014000200007

MAGUIRE, J.D. Speed of germination-aid in selection and evaluation for seedling emergence and vigor. Crop Science, v. 2, n. 2, p. 176-177, 1962.

MARCOS FILHO, J. Fisiologia de sementes de plantas cultivadas. 2. Ed. Londrina, PR: ABRATES, 2015. 660 p.

PARERA, C.A.; CANTLIFE, D.J.; STOFELLA, P.J.; SCULLY, B.T. Field emergence of shrunken-2 corn predicted by single-and multiple-vigor laboratory tests. Journal of the American Society of Horticultural Science, v. 120, n. 1, p. 128-132, 1995.

ROSSETTO, C.A.V.; NOVEMBRE, A.D.L.C.; MARCOS FILHO, J.; SILVA, W.R.; NAKAGAWA, J. Comportamento das sementes de soja durante a fase inicial do processo de germinação. Scientia Agrícola, v. 54, n. 1/2, p. 106-15, 1997. http://dx.doi.org/10.1590/S0103-90161997000100015

SHIOGA, P.S.; SILVA, W.R. Controle da hidratação das sementes e desenvolvimento inicial de plântulas do feijoeiro. Scientia Agrícola, v. 55, n. 1, p. 8-14, 1998. http://dx.doi.org/10.1590/S0103-90161998000100003 
SILVA, B.M.S.; CARVALHO, N.M. Efeitos do estresse hídrico sobre o desempenho germinativo da semente de faveira (Clitoria fairchildiana R.A. Howard. - FABACEAE) de diferentes tamanhos. Revista Brasileira de Sementes, v. 30, n. 1, p. 55-65, 2008. http://dx.doi.org/10.1590/S0101-31222008000100008

SILVA, L.F.; ROSSETO, C.A.V. Potencial fisiológico de sementes de girassol influenciado pelo umedecimento artificial. Ciência Rural, v. 42, n. 7, p. 1161-1167, 2012. http://dx.doi.org/10.1590/S010384782012000700004

SILVA, J.B.; VIEIRA, R.D. Deterioração controlada em sementes de beterraba. Revista Brasileira de Sementes, v. 32, n. 1, p. 69-76, 2010. http://dx.doi.org/10.1590/S0101-31222010000100008

TANAKA, M.A.S.; MARIANO, M. I. A.; LEÃO, N. V. M. Influência da quantidade de água no substrato sobre a germinação de sementes de amendoim. Revista Brasileira de Sementes, v. 13, n. 1, p. 73-76, 1991. http://dx.doi.org/10.17801/0101-3122/rbs.v13n1p73-76

TOMES, L.J.; TEKRONY, D. M.; EGLI, D. B. Factors influencing the tray accelerated aging test for soybean seed. Journal of Seed Technology, v. 12, n. 1, p. 24-36, 1988.

TORRES, S.B.; DANTAS, A.H.; PEREIRA, M.F.S.; BENEDITO, C.P; SILVA, F.H.A. Deterioração controlada em sementes de coentro. Revista Brasileira de Sementes, v. 34, n. 2, p. 319-326, 2012. http://dx.doi.org/10.1590/S0101-31222012000200018

TORRES, S.B.; GOMES, M.D.A.; SILVA, F.G.; BENEDITO, C.P.; PEREIRA, F.E.C.B. Controlled deterioration to evaluate okra seed vigor. Horticultura Brasileira, v. 31, n. 2, p. 317-321, 2013. http://dx.doi.org/10.1590/S0102-05362013000200023

VIEIRA, R.D.; KRZYZANOWSKI, F.C. Teste de condutividade elétrica. In: KRZYZANOWSKI, F.C.; VIEIRA, R.D.; FRANÇA NETO, J.B. (Ed). Vigor de sementes: conceitos e testes. Londrina: ABRATES. 1999. Cap.4, p. 1-26.

VILLELA, F.A.; MARCOS FILHO, J.; NOVEMBRE, A.D.L.C. Estado energético da água na semente de milho no processo de germinação. Revista Brasileira de Sementes, v. 25, n. 01, p. 95-100, 2003.

http://dx.doi.org/10.1590/S0101-31222003000100015

VILLELA, F.A.; NOVEMBRE, A.D.L.C.; MARCOS FILHO, J. Estado energético da água na germinação de sementes de soja. Revista Brasileira de Sementes, v. 29, n. 01, p. 27-34, 2007.

https://www.agrolink.com.br/downloads/86658.pdf

ZUCARELI, C.; CAVARIANI, C.; PORTUGAL, G.; NAKAGAWA, J. Potencial fisiológico de sementes de milho hidratadas pelo método do substrato de papel toalha. Revista Brasileira de Sementes, v. 30, n. 3, p. 122 129, 2008. http://dx.doi.org/10.1590/S0101-31222008000300016

ZUCARELI, C.; CAVARIANI, C.; OLIVEIRA, E.A.P; NAKAGAWA, J. Métodos e temperaturas de hidratação na qualidade fisiológica de sementes de milho. Revista Ciência Agronômica, v. 42, n. 3, p. 684692, 2011. http://ccarevista.ufc.br/seer/index.php/ccarevista/article/view/1420/593 